\title{
PENGARUH KUALITAS AUDIT, FINANCIAL DISTRESS, DEBT DEFAULT TERHADAP PENERIMAAN OPINI AUDIT GOING CONCERN
}

\author{
SISTER CLARA ISLAMY KESUMOJATI, TRI WIDYASTUTI, DAN DARMANSYAH \\ MAGISTER AKUNTANSI UNIVERSITAS PANCASILA \\ E-mail: clara_islamy@yahoo.com
}

\begin{abstract}
Abstrak
Opini going concern yang diterima oleh sebuah perusahaan menunjukkan adanya kondisi dan peristiwa yang menimbulkan keraguan auditor akan kelangsungan hidup perusahaan. Opini audit going concern dapat digunakan sebagai peringatan awal bagi para pengguna laporan keuangan guna menghindari kesalahan dalam pembuatan keputusan. Studi ini bertujuan untuk meneliti pengaruh kualitas audit, financial distress, debt default terhadap penerimaan opini audit going concern. Sampel yang digunakan dalam penelitian ini adalah perusahaan yang terdaftar di Bursa Efek Indonesia perioda tahun 2011-2015. Pengambilan sampel dengan menggunakan purposive sampling dan diperoleh sampel sebanyak 160 observasi dari 32 perusahaan yang dijadikan sampel dalam penelitian ini. Pengujian hipotesis dilakukan dengan menggunakan regression logistic. Hasil pengujian hipotesis menunjukkan bahwa kualitas audit tidak berpengaruh signifikan terhadap opini audit going concern. Sedangkan variabel financial distress dan debt default berpengaruh signifikan terhadap opini audit going concern.
\end{abstract}

Kata kunci: Opini Audit Going Concern, Kualitas Audit, Financial Distress, Debt Default

\section{PENDAHULUAN}

Setiap perusahaan ataupun organisasi pasti menginginkan tujuannya tercapai secara efektif dan efisien. Terlebih lagi dalam situasi globalisasi seperti masa sekarang ini, persaingan dalam dunia bisnis semakin ketat perusahaan harus mampu bersaing dengan perusahaan pesaingnya agar dapat bertahan.
Masalah going concern merupakan hal yang cukup kompleks dan terus ada, sehingga diperlukan faktor-faktor sebagai tolak ukur yang pasti untuk menentukan status going concern pada perusahaan. Berikut ini merupakan tabel perusahaan delisting dari tahun 2011 sampai dengan tahun 2015 pada Bursa Efek Indonesia.

Tabel 1. Perusahaan Delisting Pada Bursa Efek Indonesia

\begin{tabular}{|c|c|c|c|}
\hline Tahun & Jumlah Emiten & Pertambahan/Tahun & Delisting \\
\hline 2011 & 442 & 20 & 5 \\
\hline 2012 & 463 & 21 & 4 \\
\hline 2013 & 486 & 23 & 7 \\
\hline 2014 & 509 & 23 & 1 \\
\hline 2015 & 525 & 16 & 3 \\
\hline
\end{tabular}

Sumber: sahamok

Fenomena yang terjadi di lapangan menunjukkan banyak dari perusahaan yang go public mengalami delisting. Beberapa peneliti yang melakukan penelitian dengan pendekatan model kebangkrutan untuk memprediksi perusahaan yang mengalami kesulitan keuangan sampai dengan kategori bangkrut (delisting pada bursa) membuktikan dengan jumlah yang signifikan bahwa lebih dari $20 \%$ perusahaan terprediksi bangkrut 
dan menerima opini going concern (Fatmawati 2010). Fenomena yang terjadi di lapangan pun menunjukkan banyak dari perusahaan yang go public yang mengalami masalah going concern diragukan dalam melanjutkan kelangsungan hidupnya.

Dalam kondisi ekonomi saat ini, banyak tambahan informasi pada laporan tahunan dibanding sebelumnya yang mengandung pengungkapan terkait dengan going concern. Going concern sendiri merupakan konsep yang menganggap bahwa suatu perusahaan akan hidup terus, dalam arti diharapkan tidak akan terjadi likuidasi di masa yang akan datang. Asumsi going concern adalah salah satu asumsi yang dipakai dalam menyusun laporan keuangan suatu entitas ekonomi. Asumsi ini mengharuskan entitas ekonomi secara operasional dan keuangan memiliki kemampuan mempertahankan kelangsungan hidupnya (Purba, 2009:21).

Banyak orang menganggap bahwa opini wajar tanpa pengecualian (clean opinion) yang diberikan oleh auditor adalah jaminan bahwa suatu perusahaan tidak akan pailit dalam waktu dekat. Akibat anggapan ini, banyak auditor kemudian dihakimi berdasarkan pailit tidaknya suatu perusahaan. Chen dan Church (1996) dalam Oktavia (2010) mengatakan bahwa meskipun auditor tidak bertanggung jawab untuk memprediksi kepailitan, tetapi investor berharap kepada auditor untuk berperan dalam memberi peringatan (early warning signal) terhadap kelangsungan usaha perusahaan. Oleh karena itu penting bagi investor dan orang lain dalam dunia bisnis untuk tidak mengambil kesimpulan yang salah terkait dengan pengungkapan tersebut karena hal ini bisa melemahkan kepercayaan bisnis sehingga memperburuk situasi ekonomi secara keseluruhan.

Selama ini terdapat beberapa kasus yang terjadi, ketika auditor melakukan kesalahan dalam mendeteksi kelangsungan hidup perusahaan, yaitu dengan diberikannya jenis pendapat wajar tanpa pengecualian (unqualified opinion) atas masalah ketidakpastian kelangsungan hidup perusahaan sedangkan perusahaan mengalami kebangkrutan pada tahun berikutnya (Prayitno, 2011). Penelitian yang dilakukan oleh Prayitno (2011) menunjukkan bahwa kualitas audit berpengaruh signifikan terhadap opini audit going concern.

Faktor keuangan yang meliputi financial distress serta debt default menggambarkan tingkat kesehatan suatu perusahaan. Ross et al dalam Astuti (2011) mengungkapkan bahwa indikasi kebangkrutan dapat dilihat dari apakah perusahaan mengalami kesulitan keuangan (financial distress), yaitu suatu kondisi dimana arus kas operasi perusahaan tidak mencukupi untuk memenuhi kewajiban lancarnya. Indikator going concern yang banyak digunakan oleh auditor dalam memberikan keputusan opininya adalah kegagalan dalam memenuhi kewajiban hutangnya (default). Jadi jika perusahaan sedang dalam kondisi default maka kemungkinan perusahaan tersebut mengalami kebangkrutan. Pada kondisi keuangan perusahaan yang buruk banyak ditemukan masalah going concern.

Penelitian ini bertujuan untuk menguji kembali faktor-faktor yang mempengaruhi penerimaan opini audit going concern. Hal tersebut dikarenakan adanya perbedaan hasil dalam penelitian para peneliti sebelumnya. Dampak akan opini going concern atas laporan keuangan auditee yaitu hilangnya kepercayaan pemakai laporan keuangan terhadap manajemen perusahaan dalam mengelola perusahaan.

Penelitian yang pernah dilakukan oleh Januarti (2009) menemukan bahwa kualitas audit berpengaruh terhadap opini going concern sedangkan Surbakti (2010) menemukan bahwa kualitas audit tidak berpengaruh terhadap opini going concern. Fauziah (2015) menemukan bahwa financial distress terbukti memiliki pengaruh positif terhadap penerimaan opini going concern. 
Sementara itu Januarti (2009) dan Wahyu (2009) menunjukkan bahwa financial distress tidak berpengaruh signifikan terhadap opini going concern. Praptitorini dan Januarti (2007) mengemukakan bahwa debt default secara signifikan berpengaruh positif terhadap penerimaan opini audit going concern, sedangkan penelitian Rizki dan Indah (2014) justru menunjukkan sebaliknya bahwa debt default tidak berpengaruh terhadap penerimaan opini audit going concern. Oleh karena itu penelitian ini dilakukan untuk menganalisis pengaruh kualitas audit, financial distress dan debt default terhadap penerimaan opini audit going concern.

\section{KAJIAN TEORI DAN PENGEMBANGAN HIPOTESIS}

Teori Keagenan (Agency Theory)

Menurut Jensen dan Meckling (1976) (dalam Praptitorini dan Januarti, 2007) menyatakan bahwa hubungan agensi merupakan hubungan kontrak antara prinsipal dan agen yaitu prinsipal dalam hal ini shareholder (pemegang saham) mendelegasikan pertanggungjawaban atas decision making atau tugas tertentu kepada agen (manajer) sesuai dengan kontrak kerja yang telah disepakati. Manajer sebagai pengelola perusahaan lebih banyak mengetahui informasi dalam internal dan prospek perusahaan di masa yang akan datang dibandingkan pemegang saham. Oleh karena itu, manajer berkewajiban memberikan informasi mengenai kondisi perusahaan yang sebenarnya melalui pengungkapan informasi akuntansi seperti laporan keuangan.

Menurut Wolk dkk, (1989) dalam Sofyan (2012:532) teori ini bercerita tentang monitoring berbagai macam biaya dan memaksakan hubungan di antara kelompok ini. Audit misalnya dianggap sebagai alat meyakinkan diri bahwa laporan keuangan harus tergantung pada pemeriksaan dari aspek pengawasan intern.
Gavious (2007) mengatakan bahwa masalah keagenan auditor bersumber pada mekanisme kelembagaan antara auditor dan manajemen. Di satu pihak, auditor ditunjuk oleh manajemen untuk melakukan audit bagi kepentingan pemegang saham, namun di lain pihak, jasa audit dibayar dan ditanggung oleh manajemen. Hal ini menciptakan benturan kepentingan yang tidak dapat dihindari oleh auditor. Mekanisme kelembagaan ini menimbulkan ketergantungan auditor kepada kliennya, sehingga auditor merasa kehilangan independensinya dan harus mengkomodasi berbagai keinginan klien, dengan harapan agar perikatan auditnya di masa depan tidak terputus. Konsisten dengan teori agensi, manajemen perusahaan senantiasa mencoba untuk memuaskan keinginan investor dengan memilih auditor yang dapat merefleksikan citra manajer yang baik di mata investor. Kualitas pelayanana jasa auditor yang diberikan terhadap klien merupakan dasar pertimbangan utama untuk menyeleksi auditor.

\section{Opini Audit Going Concern}

Opini audit going concern merupakan opini audit yang dikeluarkan oleh auditor untuk mengevaluasi apakah ada kesangsian tentang kemampuan entitas untuk mempertahankan kelangsungan hidupnya (SPAP, 2001). Auditor menetapkan penerimaan opini audit going concern apabila dalam proses audit ditemukan kondisi dan peristiwa yang mengarah pada kesangsian terhadap kelangsungan hidup perusahaan. Menurut Purba (2009:21) asumsi going concern adalah salah satu asumsi yang dipakai dalam menyusun laporan keuangan suatu entitas ekonomi. Asumsi ini mengharuskan entitas ekonomi secara operasional dan keuangan memiliki kemampuan mempertahankan kelangsungan hidupnya atau going concern. Sedangkan menurut Belkaoui (2006:271), going concern adalah dalil yang menyatakan bahwa suatu entitas akan menjalankan terus operasinya 
dalam jangka waktu yang cukup lama untuk mewujudkan proyeknya, tanggung jawab, serta aktivitas-aktivitasnya yang tiada henti.

\section{Kualitas Audit}

Pengukuran kualitas audit masih tetap merupakan sesuatu yang tidak jelas, tetapi pemakai laporan keuangan biasa mengaitkannya dengan reputasi auditor. Teoh \& Wong, (1993) dan Craswell et al. (1995) dalam Rahman dan Siregar (2011) menyatakan bahwa auditor yang memiliki reputasi yang baik akan cenderung untuk mempertahankan kualitas auditnya agar reputasinya terjaga dan tidak kehilangan klien. Berdasarkan penelitian-penelitian terdahulu, proksi yang sering digunakan untuk menilai kualitas audit adalah dengan menggunakan skala kantor akuntan publik McKinley et al. (1985) dalam Fanny dan Saputra (2005) yang menyatakan bahwa ketika sebuah Kantor Akuntan Publik (KAP) mengklaim dirinya sebagai KAP besar seperti yang dilakukan oleh big four firms, maka mereka akan berusaha keras untuk menjaga nama besar tersebut, mereka akan menghindari tindakan-tindakan yang dapat mengganggu nama besar mereka. Hal ini sejalan dengam penelitian yang dilakukan oleh Prayitno (2011), yang menunjukkan bahwa kualitas audit berpengaruh signifikan terhadap opini audit going concern.

Berdasarkan hal-hal tersebut diajukan hipotesis sebagai berikut:

H1: Kualitas audit diduga berpengaruh terhadap opini audit going concern.

\section{Financial Distress}

Dalam Fauziah (2015) financial distress merupakan situasi dimana aliran kas operasi suatu perusahaan tidak cukup memuaskan kewajiban-kewajibannya. Kondisi keuangan perusahaan dalam keadaan baik atau buruk dapat digambarkan dengan rasio keuangan. Perusahaan yang sedang mengalami kesulitan keuangan akan terlihat secara kasat dari laba yang dihasilkan. Jika laba menurun dengan ketentuan tertentu maka perusahan dapat dikategorikan sebagai perusahaan yang distress. Perusahaan yang mengalami financial distress kemungkinan besar akan mendapat opini audit going concern karena perusahaan tersebut mengindikasikan kelangsungan hidup yang diragukan dan terancam bangkrut. Dalam perhitungannya financial distress menggunakan model prediksi kebangkrutan Altman revisi yaitu semakin kecil nilai Z-score, perusahaan semakin mengalami financial distress. Maka dapat dikatakan bahwa perusahaan yang mengalami financial distress dengan nilai Zscore semakin kecil, maka besar kemungkinan menerima opini audit going concern. Hal tersebut sejalan dengan penelitian yang dilakukan oleh Mada dan Laksito (2013) yang menunjukkan hasil bahwa financial distress berpengaruh terhadap penerimaan opini going concern.

Berdasarkan hal tersebut diajukan hipotesis sebagai berikut:

H2: Financial distress diduga berpengaruh terhadap opini audit going concern.

\section{Debt Default}

Dalam PSA 30 paragraf 6 going concern yang banyak digunakan auditor dalam memberikan keputusan opini audit adalah kegagalan dalam memenuhi kewajiban hutangnya (default). Debt default didefinisikan sebagai kegagalan debitor (perusahaan) untuk membayar hutang pokok dan bunganya pada waktu jatuh tempo (Chen dan Church, 1992). Hal pertama yang akan dilakukan oleh auditor untuk mengetahui kondisi kesehatan keuangan suatu perusahaan adalah dengan memeriksa hutang perusahaan. Ketika suatu perusahaan memiliki hutang yang tinggi, maka kas yang ada di perusahaan akan diarahkan untuk menutup hutang yang dimiliki perusahaan yang dampaknya akan mengganggu kegiatan operasional perusahaan. Perusahaan yang tidak mampu membayar utang pokok atau bunganya pada saat jatuh tempo (debt 
default) maka kemungkinan besar perusahaan akan menerima opini audit going concern. Pradiptorini dan Januarti (2007) menemukan hubungan yang kuat status default terhadap opini going concern. Hasil temuannya menyatakan bahwa kesulitan dalam mentaati persetujuan hutang, faktafakta pembayaran yang lalai atau pelanggaran perjanjian, memperjelas masalah going concern suatu perusahaan.

Berdasarkan hal tersebut diajukan hipotesis sebagai berikut :

H3: Debt default diduga berpengaruh terhadap opini audit going concern.

\section{METODE PENELITIAN \\ Populasi dan Sampel}

Populasi data dalam penelitian ini adalah perusahaan yang terdaftar di Bursa Efek Indonesia (BEI). Sampel adalah bagian dari jumlah maupun karakteristik yang dimiliki oleh populasi tersebut (Sugiyono, 2007:73). Sampel yang gunakan dalam penelitian ini yaitu data sekunder eksternal seperti laporan auditor independen, dan laporan keuangan tahunan perusahaan yang terdaftar di BEl dengan periode pengamatan tahun 2011 sampai dengan 2015.

\section{Metode Pemilihan Data}

Tabel 2. Kriteria Pengambilan Sampel

\begin{tabular}{|l|l|}
\hline $\begin{array}{l}\text { Jumlah perusahaan yang terdaftar pada Bursa Efek Indonesia } \\
\text { (2011-2015) }\end{array}$ & 524 \\
\hline Perusahaan delisting (2011-2015) & $(20)$ \\
\hline Perusahaan yang tidak menerima opini audit going concern & $(438)$ \\
\hline $\begin{array}{l}\text { Perusahaan yang menerima opini audit going concern minimal 1 } \\
\text { kali dalam 5 tahun penelitian }\end{array}$ & 66 \\
\hline Data laporan keuangan tidak lengkap & $(34)$ \\
\hline Jumlah perusahaan yang dijadikan sampel & 32 \\
\hline Tahun pengamatan & 5 \\
\hline Jumlah sampel total selama periode penelitian & 160 \\
\hline
\end{tabular}

Sumber : BEI, data diolah.

\section{Metode Analisis Data}

Analisis data dalam penelitian ini dilakukan dengan menggunakan regresi logistik karena variabel terikatnya yaitu opini audit going concern merupakan data kualitatif yang menggunakan variabel dummy dan variabel bebasnya merupakan kombinasi antara variabel metrik dan non metrik. Ghozali (2006:225) menyatakan bahwa regresi logistik digunakan untuk menguji apakah probabilitas terjadinya variabel terikat dapat diprediksi dengan variable bebasnya. Teknik analisis regresi logistik tidak memerlukan asumsi normalitas data pada variabel bebasnya (Ghozali, 2006:225), dan mengabaikan heteroskedastisitas. Model regresi logistik yang digunakan untuk menguji hipotesis sebagai berikut:

GCit = a + b1 SPESIAL + b2 DEFAULTit + b3 BANKRUPTit

Keterangan:

SPESIALit : Auditor industry specialization

(variabel dummy, 1 jika auditor spesialis, 0

jika bukan auditor spesialis).

DEFAULTit: Debt default (variabel dummy, 1

jika perusahaan dalam keadaan default, dan 0 jika tidak).

BANKRUPTit : Prediksi kebangkrutan

menggunakan persamaan revised Altman. 


\section{Definisi Operasional dan Pengukurannya Variabel Dependen}

Variabel dependen dalam penelitian ini adalah opini audit going concern. Opini going concern adalah asumsi yang menyatakan bahwa suatu entitas dapat terus beroperasi mempertahankan kelangsungan hidupnya dalam jangka waktu yang lama. Opini audit yang termasuk kedalam opini going concern merupakan opini audit yaitu laporan yang berisi wajar tanpa pengecualian dengan bahasa penjelas. Variabel ini dikukur dengan variable dummy, dimana kategori 0 untuk pendapat wajar tanpa pengecualian, dengan opini tersebut dikategorikan perusahaan going concern, sedangkan kategori 1 untuk pendapat wajar tanpa pengecualian dengan bahasa penjelas, pendapat wajar, pendapat tidak wajar dan tidak memberikan pendapat dengan demikian perusahaan dikategorikan non going concern.

\section{Variabel Independen}

Variabel bebas atau independen adalah variabel yang memengaruhi atau yang menjadi sebab perubahannya atau timbulnya variabel dependen atau terikat (Sugiyono, 2007:33). Variabel independen dalam penelitian ini adalah sebagai berikut:

\section{Kualitas Audit (X1)}

Kualitas auditor diukur dengan reputasi auditor yang merupakan prestasi dan kepercayaan publik yang disandang auditor atas nama besar yang dimiliki auditor tersebut seperti akuntan publik yang termasuk kedalam big four firms. Dalam penelitian ini kualitas audit diproksikan dengan menggunakan skala auditor. Variabel ini diukur dengan menggunakan variabel dummy 1 untuk auditor yang tergabung dalam skala besar dan 0 untuk auditor yang bukan.

\section{Financial Distress (X2)}

Kondisi keuangan perusahaan yang dipresentasikan dari tingkat kesehatan perusahaan. Kondisi kesehatan ini ditunjukan oleh rasio-rasio keuangan perusahaan yang mengindikasikan perusahaan dalam keadaan baik (sehat) atau buruk (sakit). Klasifikasi perusahaan yang sehat dan bangkrut didasarkan pada nilai Z-score model Altman revisi yaitu jika nilai $Z<1,23$ maka termasuk perusahaan yang bangkrut. Jika nilai $1,23<\mathrm{Z}$ $<2,9$ maka termasuk grey area (tidak dapat ditentukan apakah perusahaan sehat ataupun mengalami kebangkrutan) sedangkan jika nilai $Z>2,9$ maka merupakan perusahaan yang tidak bangkrut. Formulanya adalah:

\section{$Z^{\prime}=0.717 Z 1+0.874 Z 2+3.107 Z 3+0.420 Z 4+$ $0.998 Z 5$}

Keterangan:

$$
\mathrm{Z1}=\text { Net working capital/ }
$$

total assets

$\mathrm{Z2}=$ Retained earnings $/$ total

assets

$\mathrm{Z3}=$ Earnings before interest and taxes/total assets

book value of debt

$\mathrm{Z4}=$ Book value of equity/

$\mathrm{Z} 5=$ Sales $/$ total assets

\section{Debt Default (X3)}

Debt default atau kegagalan membayar hutang didefinisikan sebagai kelalaian atau kegagalan perusahaan untuk membayar hutang pokok atau bunganya pada saat jatuh tempo. Debt default ini digunakan oleh auditor untuk menilai kelangsungan hidup suatu perusahaan.. Variabel dummy digunakan ( 1 = status debt default, $0=$ tidak debt default) untuk menunjukkan apakah perusahaan dalam keadaan default atau tidak. Status debt default biasanya ada atau terungkap di catatan atas laporan keuangan pada penjelasan atas laporan keuangan (pada pos utang) atau dalam opini audit.

\section{HASIL PENELITIAN DAN PEMBAHASAN Hasil Uji Statistik Deskriptif}

Hipotesis dalam penelitian ini diuji dengan menggunakan model regresi logistik 
(logistic regression). Tujuannya adalah untuk memperoleh gambaran menyeluruh mengenai pengaruh variabel independen (pengaruh kualitas audit, financial distress, debt default) terhadap variabel dependen yaitu opini audit going concern. Berdasarkan kriteria sampel dan prosedur penyampelan yang telah dilakukan diperoleh 32 perusahaan dengan 160 sampel dalam tahun pengamatan. Data yang digunakan dalam penelitian ini diambil dari laporan auditor independen dan laporan keuangan perusahaan.

Perhitungan statistik deskriptif digunakan untuk mengetahui karakteristik dari sampel penelitian yang digunakan atau dianalisis lebih lanjut. Perhitungan yang dilakukan meliputi jumlah sampel, standar deviasi, nilai minimum dan nilai maximum. Pengolahan data dengan mengunakan program SPSS for windows versi 22.0.

Tabel 3. Uji Statistik Deskriptif

\begin{tabular}{|l|l|l|l|l|l|}
\hline & $\mathrm{N}$ & Min & Maxi & Mean & $\begin{array}{l}\text { Std. } \\
\text { Deviation }\end{array}$ \\
\hline Going Concern & 160 & 0 & 1 & 0.72 & 0.451 \\
Kualitas Audit & 160 & 0 & 1 & 0.23 & 0.423 \\
Financial & & - & & & \\
Distress & 160 & 67.89 & 1697.24 & 21.706 & 172.49955 \\
Debt Default & 160 & 0 & 1 & 0.61 & 0.49 \\
Valid N & & & & & \\
(listwise) & 160 & & & & \\
\hline
\end{tabular}

Sumber : data diolah

Dari hasil analisis deskriptif di atas menunjukkan variabel penelitian opini audit going concern memiliki nilai rata-rata variabel sebesar 0,72 yang lebih besar dari 0,50 menunjukkan bahwa opini audit dengan kode 1, yakni opini audit going concern lebih banyak muncul dari 160 perusahaan sampel yang diteliti. Dari 160 perusahaan sampel, 115 perusahaan sampel menerima opini audit going concern, dan sisanya sebesar 45 perusahaan sampel menerima opini audit non going concern.

Variabel kualitas audit memiliki nilai rata-rata sebesar 0,23 yang lebih kecil dari 0,50 menunjukkan bahwa kualitas audit dengan kode 1, yakni KAP yang berafiliasi dengan big four lebih sedikit muncul dari 160 perusahaan sampel. Dari 160 perusahaan sampel, 36 perusahaan sampel diaudit oleh KAP yang berafiliasi dengan big four, dan 124 perusahaan sampel diaudit oleh KAP yang tidak berafiliasi dengan big four. Hal ini mengindikasikan bahwa baik KAP big four maupun non big four memilki peluang yang sama besar dalam memberikan opini going concern terhadap perusahaan yang bermasalah.

Variabel financial distress memiliki nilai rata-rata yang positif yaitu sebesar 28,46 dengan nilai minimum $-67,89$ dan nilai maksimum 1697,24. Nilai yang positif (maksimum) menggambarkan kondisi keuangan yang tinggi atau baik, sedangkan nilai yang negatif (minimum) menggambarkan kondisi keuangan yang rendah atau kurang baik. Kondisi keuangan yang tinggi atau baik bukan berarti akan terhindar dari opini going concern, karena auditor lebih percaya pada hasil auditnya untuk memberikan opini going concern maupun non going concern. 
Variabel penelitian debt default memiliki nilai rata-rata variabel sebesar 0,61 yang lebih besar dari 0,50 menunjukkan bahwa debt default dengan kode 1, yakni perusahaan yang mengalami debt default banyak muncul dari 160 perusahaan sampel yang diteliti. Dari 160 perusahaan sampel, 98 perusahaan sampel mengalami kondisi debt default, dan sisanya sebesar 62 perusahaan sampel tidak mengalami kondisi debt default.

\section{Hasil Uji Hipotesis}

Analisis data dalam penelitian ini dilakukan dengan menggunakan regresi logistik. Ghozali (2006:225) menyatakan bahwa regresi logistik digunakan untuk menguji apakah probabilitas terjadinya variabel terikat dapat diprediksi dengan variabel bebasnya. Teknik analisis regresi logistik tidak memerlukan asumsi normalitas data pada variabel bebasnya (Ghozali, 2006:225), dan mengabaikan heteroskedastisitas (Gujarati, 2003:597).

\section{Menilai Kelayakan Model Regresi}

Pengujian kelayakan model regresi logistik dilakukan dengan menggunakan goodness of fit test yang diukur dengan nilai chi-Square pada bagian bawah uji homser and lemeshow. Probabilitas signifikansi yang diperoleh kemudian dibandingkan dengan tingkat signifikasi $5 \%$.

Tabel 4. Uji kelayakan Model Regresi

\begin{tabular}{|l|l|l|l|}
\hline Step & Chi-square & Df & Sig. \\
\hline 1 & 15.133 & 8 & 0.057 \\
\hline
\end{tabular}

Sumber : data diolah

Hasil dari hosmer and lemeshow's goodness of fit test menunjukkan nilai probabilitas 0,57. Nilai signifikansi yang diperoleh jauh lebih besar dari 0,05, maka hipotesis nol tidak dapat ditolak (diterima) yang berarti tidak terdapat perbedaan yang nyata antara model dengan nilai-nilai observasinya sehingga model dapat memprediksi hasil observasi dengan baik. Hal ini berarti model regresi layak untuk digunakan dalam analisis selanjutnya, karena tidak ada perbedaan yang nyata antara klasifikasi yang diprediksi dengan klasifikasi yang diamati.

\section{Menilai Keseluruhan Model (Overall Model} Fit)

Pengujian ini dilakukan untuk mengetahui apakah model fit dengan data baik sebelum maupun sesudah variabel bebas dimasukkan kedalam model. Dalam penelitian ini untuk menilai model fit digunakan fungsi likelihood. Likelihood L dari model adalah probabilitas bahwa model yang dihipotesiskan menggambarkan data input.

Tabel 5. Uji Keseluruhan Model

-2 log likehood (-2LL) awal

Iteration History $\mathrm{a}, \mathrm{b}, \mathrm{c}$

\begin{tabular}{|c|c|c|c|}
\hline \multirow{2}{*}{\multicolumn{2}{|c|}{ Iteration }} & \multirow{2}{*}{$\begin{array}{l}-2 \text { Log } \\
\text { likelihood }\end{array}$} & Coefficients \\
\hline & & & Constant \\
\hline \multirow{3}{*}{$\begin{array}{l}\text { Step } \\
0\end{array}$} & 1 & 190.252 & 0.875 \\
\hline & 2 & 190.122 & 0.937 \\
\hline & 3 & 190.122 & 0.938 \\
\hline
\end{tabular}

Sumber : data diolah 
Tabel 6. Uji Keseluruhan Model

-2 log likehood (-2LL) akhir

Iteration History $\mathrm{a}^{\mathrm{a}, \mathrm{b}, \mathrm{c}, \mathrm{d}}$

\begin{tabular}{|c|c|c|c|c|c|c|}
\hline \multirow{2}{*}{\multicolumn{2}{|c|}{ Iteration }} & \multirow{2}{*}{$\begin{array}{l}-2 \text { Log } \\
\text { likelihood }\end{array}$} & \multicolumn{4}{|c|}{ Coefficients } \\
\hline & & & Constant & $\mathrm{X} 1$ & $\mathrm{X} 2$ & X3 \\
\hline \multirow{8}{*}{$\begin{array}{l}\text { Step } \\
1\end{array}$} & 1 & 172.639 & 0.597 & -0.569 & -0.003 & 0.768 \\
\hline & 2 & 170.003 & 0.654 & -0.691 & -0.005 & 0.974 \\
\hline & 3 & 168.425 & 0.666 & -0.709 & -0.008 & 1.001 \\
\hline & 4 & 166.641 & 0.68 & -0.709 & -0.015 & 0.988 \\
\hline & 5 & 164.113 & 0.728 & -0.706 & -0.038 & 0.937 \\
\hline & 6 & 163.982 & 0.751 & -0.719 & -0.044 & 0.937 \\
\hline & 7 & 163.982 & 0.753 & -0.72 & -0.044 & 0.937 \\
\hline & 8 & 163.982 & 0.753 & -0.72 & -0.044 & 0.937 \\
\hline
\end{tabular}

Sumber : data diolah

Penilaian keseluruhan model dilakukan dengan membandingkan nilai antara -2 log likelihood (-2LL) pada awal (block number $=$ $0)$, yaitu model hanya memasukkan konstanta dengan nilai -2 log likelihood (-2LL) pada akhir (block number $=1$ ), dimana model memasukkan konstanta dan variabel bebas. Nilai -2LL awal adalah sebesar 190,122 dan setelah dimasukkan variabel independen, maka nilai -2LL akhir mengalami penurunan menjadi sebesar 163,982 . Penurunan nilai $2 \mathrm{LL}$ ini menunjukkan model regresi yang baik atau dengan kata lain model yang dihipotesiskan fit dengan data.

\section{Koefisien Determinasi (Nagelkerke R Square)}

Koefisien determinasi digunakan untuk mengetahui seberapa besar variabilitas variabel-variabel independen mampu memperjelas variabilitas variabel dependen. Koefisien determinasi pada regresi logistik dapat dilihat pada nilai Nagelkerke $R$ Square. Nilai Nagelkerke $R$ Square dapat diinterpretasikan seperti nilai $R$ Square pada regresi berganda (Ghozali, 2006: 79). Nilai ini didapat dengan cara membagi nilai Cox \& Snell $R$ Square dengan nilai maksimumnya.

Tabel 7. Uji Koefisien Determinasi Model Summary

\begin{tabular}{|l|l|l|l|}
\hline & & $\begin{array}{l}\text { Cox \& Snell R } \\
\text { Square }\end{array}$ & $\begin{array}{l}\text { Nagelkerke R } \\
\text { Square }\end{array}$ \\
\hline 1 & -2 Log likelihood & 0.151 & 0.217 \\
\hline
\end{tabular}

Sumber : data diolah 
Besarnya nilai koefisien determinasi pada model regresi logistik ditunjukkan dengan nilai Nagelkerke $R$ square. Berdasarkan hasil pengujian yang ditunjukkan pada Tabel 4.7, nilai Nagelkerke $R$ square adalah sebesar 0,217 yang berarti variabilitas variabel dependen yang dapat dijelaskan oleh variabel independen adalah sebesar 21,7 persen, sedangkan sisanya sebesar 78,3 persen dijelaskan oleh variabel-variabel lain di luar model penelitian.

\section{Tabel Klasifikasi}

Tabel klasifikasi menunjukkan kekuatan prediksi dari model regresi untuk memprediksi probabilitas penerimaan opini audit going concern oleh perusahaan. Kekuatan prediksi dari model regresi untuk memprediksi kemungkinan terjadinya variabel terikat dinyatakan dalan persen.

Tabel 8. Tabel Klasifikasi

Classification Table

\begin{tabular}{|c|c|c|c|c|c|}
\hline & \multirow[b]{3}{*}{ Observed } & & \multicolumn{3}{|l|}{ Predicted } \\
\hline & & & \multicolumn{2}{|l|}{ Going Concern } & \multirow[b]{2}{*}{$\begin{array}{l}\text { Percentage } \\
\text { Correct }\end{array}$} \\
\hline & & & $\begin{array}{l}\text { Non } \\
\text { GoingConcern }\end{array}$ & GoingConcern & \\
\hline \multirow{4}{*}{$\begin{array}{l}\text { Step } \\
1\end{array}$} & Going & Non & & & \\
\hline & Concern & GoingConcern & 13 & 32 & 28.9 \\
\hline & & GoingConcern & 5 & 110 & 95.7 \\
\hline & Overall $\mathrm{P}$ & rcentage & & & 76.9 \\
\hline
\end{tabular}

Sumber : data diolah

Kekuatan prediksi dari model regresi untuk memprediksi kemungkinan perusahaan menerima opini audit going concern adalah sebesar $95,7 \%$. Hal ini menunjukkan bahwa dengan menggunakan model regresi yang digunakan, terdapat sebanyak 110 laporan keuangan yang diberi opini audit going concern dari total 115 laporan keuangan yang seharusnya diberi opini audit going concern. Kekuatan prediksi model perusahaan yang tidak menerima opini audit going concern adalah sebesar $28,9 \%$, yang berarti bahwa dengan model regresi yang digunakan ada sebanyak 13 laporan keuangan yang tidak diberi opini audit going concern dari total 45 laporan keuangan yang seharusnya tidak diberi opini audit going concern.

\section{Model Regresi Logistik dan Pengujian Hipotesis.}

Pengujian koefisien regresi dapat dilakukan dengan regresi logistik yang hasilnya terdapat pada tabel berikut:

Tabel 9. Hasil Uji Koefisien Regresi Logistik

Variables in the Equation

\begin{tabular}{|ll|l|l|l|l|l|l|}
\hline & & & & & & & \\
\hline Step & X1 & B & S.E. & Wald & df & Sig. & Exp(B) \\
$1^{\text {a }}$ & X2 & - & & & & & \\
& & 0.044 & 0.019 & 5.232 & 1 & 0.022 & 0.957 \\
& X3 & 0.937 & 0.387 & 5.871 & 1 & 0.015 & 2.553 \\
& Constant & 0.753 & 0.31 & 5.894 & 1 & 0.015 & 2.123 \\
\hline
\end{tabular}

Sumber : data diolah 
Tabel 8 menunjukkan hasil pengujian dengan regresi logistik pada taraf kesalahan 5 persen. Model regresi logistik yang digunakan untuk menguji hipotesis sebagai berikut :

\section{GCit $=0,753-0,720 X 1-0,044 X 2+0,937 \times 3$}

Berdasarkan model regresi logistik yang terbentuk, dapat diinterpretasikan hasil sebagai berikut:

1. Konstanta (a) sebesar 0,753 , menyatakan bahwa jika variabel independen dianggap konstan atau nol, maka going concern sebesar 0,753.

2. Koefisien $\mathrm{XI}(\mathrm{b} 1)=-0,720$ dengan tingkat signifikansi 0,085 yang lebih besar dari signifikansi penelitian sebesar 0,05 artinya H1 ditolak, dengan demikian dapat disimpulkan bahwa variabel kualitas audit secara signifikan tidak berpengaruh terhadap opini going concern. Hasil ini menyatakan bahwa apabila kualitas audit (XI) naik sebesar 1 satuan maka going concern akan turun sebesar -0,720 dengan asumsi variabel lainnya tetap atau sama dengan nol.

3. Koefisien $X 2$ (b2) $=-0,044$ dengan tingkat signifikansi 0,022 yang lebih kecil dari signifikansi penelitian sebesar 0,05 artinya H2 diterima, dengan demikian dapat disimpulkan bahwa variabel financial distress (X2) secara signifikan berpengaruh terhadap opini going concern. Hasil ini menyatakan bahwa apabila financial distress naik sebesar 1 satuan maka going concern akan turun sebesar -0,044 dengan asumsi variabel lainnya tetap atau sama dengan nol.

4. Koefisien $X 3(b 3)=0,937$ dengan tingkat signifikansi 0,015 yang lebih kecil dari signifikansi penelitian sebesar 0,05 artinya H3 diterima, dengan demikian dapat disimpulkan bahwa variabel debt default (X3) secara signifikan berpengaruh terhadap opini going concern. Hasil ini menyatakan bahwa apabila debt default naik sebesar 1 satuan maka going concern akan naik sebesar 0,937 dengan asumsi variable lainnya tetap atau sama dengan nol.

\section{PEMBAHASAN \\ Pengaruh Kualitas Audit dan Opini Going Concern}

Hasil hipotesis pertama menyatakan kualitas audit tidak berpengaruh secara signifikan terhadap penerimaan opini audit going concern pada perusahaan. Hasil penelitian ini memberikan bukti empiris bahwa kualitas audit tidak dapat dijadikan sebagai faktor yang dapat mempengaruhi opini audit going concern. Meskipun pada kenyataannya banyak perusahaan dan investor yang hanya menggunakan jasa dari KAP yang termasuk big four saja karena ada anggapan hasil opini audit lebih dapat dipercaya dibanding KAP yang tidak masuk ke dalam big four. Palmrose (1984) serta Healy dan Lys (1986) menyatakan bahwa kualitas audit merupakan indikator utama dalam membangun teori pemilihan auditor. Artinya kualitas pelayanan jasa auditor yang diberikan terhadap klien merupakan dasar pertimbangan utama dalam menyeleksi auditor. Konsisten dengan teori agensi, manejemen perusahaan senantiasa mencoba untuk memuaskan keinginan investor dengan memilih auditor yang dapat merefleksikan citra manajer yang baik di mata investor.

Ramadhany (2004) menyatakan bahwa perusahaan audit berskala besar memiliki insentif yang lebih untuk menghindari kritikan kerusakan reputasi dibandingkan pada perusahaan audit skala kecil. Hal ini membuktikan bahwa KAP yang berafiliasi dengan KAP big four ataupun yang tidak berafiliasi dengan KAP big four sama-sama memberikan kualitas audit yang baik dan bersikap independen dalam mengeluarkan pendapat. Jika perusahaan mengalami keraguan dalam meneruskan usahannya maka akan diberikan opini audit going concern.

Peraturan mengenai pembatasan perikatan antara perusahaan dengan Akuntan 
Publik (AP) atau Kantor Akuntan Publik (KAP) ada dalam keputusan menteri keuangan nomor 359/KMK.06/2003 pada tanggal 21 Agustus 2003. Dalam peraturan tersebut diatur pembatasan perikatan yaitu tiga tahun buku berturut-turut untuk AP dan lima tahun buku berturut-turut untuk KAP dan juga diatur mengenai pembinaan dan pengawasan terhadap AP dan KAP. Kemudian tanggal 5 Februari 2008 KMK Nomor 359/KMK.06/2003 diganti menjadi PMK nomor 17/PMK.01.2008 yang saat ini masih berlaku. Peraturan tersebut mengubah batas maksimal perikatan KAP dari 5 (lima) tahun menjadi 6 (enam) tahun.

Hal ini sejalan dengan penelitian yang dilakukan oleh Komalasari (2004) pengaruh kualitas auditor dan proxi going concern terhadap opini auditor. Surbakti (2010) faktor-faktor yang mempengaruhi penerimaan opini audit going concern hasil pengujian terhadap variabel kualitas audit yang diproksikan dengan skala auditor (afiliasinya dengan KAP the big four). Bukti tersebut juga konsisten dengan penelitian yang dilakukan oleh Praptitorini dan Januarti (2007) yang menganalisis pengaruh kualitas audit, debt default dan opinion shopping terhadap penerimaan opini going concern. Sehingga tidak menemukan bukti mendukung bahwa auditor spesialis lebih sering memberikan opini going concern kepada perusahaan yang akan bangkrut.

\section{Pengujian Hipotesis Kedua (H2)}

Hasil hipotesis kedua menyatakan financial distress berpengaruh secara signifikan terhadap penerimaan opini audit going concern pada perusahaan. Dalam memberikan opini going concern, seorang auditor tentu saja sangat memperhatikan kondisi keuangan perusahaan. Perusahaan yang tidak mempunyai permasalahan keuangan yang serius, tidak mengalami kesulitan likuiditas, mempunyai modal kerja yang cukup tentu jauh dari penerimaan opini going concern. Financial distress merupakan kondisi dimana keuangan perusahaan dalam keadaan tidak sehat. Financial distress terjadi sebelum kebangkrutan. Fauziah (2010) perusahaan yang sedang mengalami kesulitan keuangan akan terlihat secara kasat dari laba yang dihasilkan. Jika laba menurun dengan ketentuan tertentu maka perusahan dapat dikatagorikan sebagai perusahaan yang distress. Mc Keown dkk. (1991) yang menyatakan bahwa auditor hampir tidak pernah mengeluarkan opini audit going concern pada perusahaan yang tidak mengalami kesulitan keuangan.

Hal ini sejalan dengan penelitian yang dilakukan oleh Azizah dan Anisykurlillah (2014) meneliti pengaruh ukuran perusahaan, debt default, kondisi keuangan perusahaan terhadap penerimaan opini audit going concern meski dengan proyeksi yang berbeda yaitu kondisi keuangan dengan hasil penelitian menunjukan kondisi keuangan berpengaruh terhadap penerimaan opini going concern. Bukti tersebut juga konsisten dengan penelitian yang dilakukan oleh Mada dan Laksito (2013) mengenai pengaruh mekanisme corporate governance, reputasi $\mathrm{KAP}$, debt default dan financial distress terhadap penerimaan opini audit going concern. Sehingga dapat disimpulkan bahwa financial distress bepengaruh signifikan terhadap penerimaan opini audit going concern.

\section{Pengujian Hipotesis Ketiga (H3)}

Hasil hipotesis ketiga debt default secara signifikan berpengaruh terhadap penerimaan opini audit going concern pada perusahaan. Hasil temuan ini berarti sesuai pernyataan yang tercantum dalam PSA No. 30 tentang kondisi yang perlu dipertimbangkan auditor dalam menilai kelangsungan hidup perusahaan, yaitu dalam salah satu point disebutkan bahwa kondisi tentang kemungkinan suatu perusahaan mengalami kesulitan keuangan yaitu kegagalan dalam memenuhi kewajiban utangnya atau perjanjian serupa. Untuk 
mengembangkan perusahaan dalam mengahadapi persaingan, maka diperlukan adanya suatu pendanaan yang bisa digunakan untuk memenuhi kebutuhan tersebut.

Pada kondisi ekstrim, kerugian tersebut dapat membahayakan perusahaan karena dapat terancam kebangkrutan dan nilai perusahaan akan berkurang tingkatnya. Untuk memenuhi kebutuhan pendanaan, pemegang saham lebih menginginkan pendanaan perusahaan dibiayai dengan hutang karena dengan penggunaan hutang, hak mereka terhadap perusahaan tidak akan berkurang. Tetapi manajer tidak menyukai pendanaan tersebut dengan alasan bahwa hutang mengandung risiko yang tinggi. Manajemen perusahaan mempunyai kecenderungan untuk memperoleh keuntungan yang sebesar-besarnya dengan biaya pihak lain. Teori keagenan yang dikemukakan oleh (Jensen dan Meckling 1976) merupakan salah satu explanatory variabel untuk mengetahui adanya variasi dalam kebijakan hutang perusahaan Salah satu sebab timbulnya konflik keagenan antara manajer dan pemegang saham disebabkan oleh keputusan pendanaan. Keputusan pendanaan secara sederhana dapat diartikan sebagai keputusan manajemen dalam menentukan sumber-sumber pendanaan dari modal internal, yakni laba ditahan atau dari modal eksternal, yakni modal sendiri dan atau melalui utang (Waluyo dan Ka'aro, 2002). Perusahaan yang tidak mampu membayar utang pokok atau bunganya pada saat jatuh tempo (debt default) maka kemungkinan besar perusahaan akan menerima opini audit going concern. Kegagalan dalam memenuhi kewajiban hutang dan atau bunga merupakan indikator going concern yang banyak digunakan oleh auditor dalam menilai kelangsungan hidup suatu perusahaan.

Hal ini sejalan dengan penelitian yang dilakukan oleh Meliyanti (2010) faktor-faktor yang mempengaruhi penerimaan opini audit going concern. Bukti tersebut juga sejalan dengan penelitian yang dilakukan oleh Praptitorini dan Januarti (2007) analisis pengaruh kualitas audit, debt default dan opinion shopping terhadap penerimaan opini going concern. Hasil temuannya menyatakan bahwa kesulitan dalam mentaati persetujuan hutang, fakta-fakta pembayaran yang lalai atau pelanggaran perjanjian, memperjelas masalah going concern suatu perusahaan.

\section{PENUTUP}

Kualitas audit tidak berpengaruh secara signifikan terhadap penerimaan opini audit going concern pada perusahaan. Sedangkan financial distress berpengaruh secara signifikan terhadap penerimaan opini audit going concern pada perusahaan. Kemudian debt default secara signifikan berpengaruh terhadap penerimaan opini audit going concern pada perusahaan.

\section{DAFTAR PUSTAKA}

Azizah, Rizki., \& Anisykurlillah, Indah. 2014. Pengaruh Ukuran Perusahaan, Debt Default, Dan Kondisi Keuangan Perusahaan Terhadap Penerimaan Opini Audit Going Concern, Accounting Analysis Journal, 3(4).

Belkaoui, Ahmed Riahi. 2006. Accounting Theory, Edisi 5. Buku 1. Penerbit Salemba Empat: Jakarta.

Chen, K. C., Church, B. K. 1992. Default on Debt Obligations and The Issuance of GoingConcern Report. Auditing: Journal Practice and Theory, Fall. pp 30-49.

Chen, K. C., Church, B. K. 1996. Going Concern Opinions and The Market's Reaction to Bankruptcy Fillings. The Accounting Review 71, 117-128.

Fanny, Margaretta dan Saputra, S. 2005. Opini Audit Going Concern : Kajian Berdasarkan Model Prediksi Kebangkrutan, Pertumbuhan Perusahaan, dan Reputasi Kantor Akuntan Publik (Studi Pada Emiten 
Bursa Efek Jakarta). Simposium Nasional Akuntansi VIII. Page 966-978.

Fatmawati, Mila. (2010). Penggunaan The Zmijewski Model, The Altman Model dan The Springate Model sebagai Prediktor Delisting. Jurnal Keuangan dan Perbankan. Volume 16 no.1.

Fauziyah. 2015. Pengaruh Financial Distress terhadap Opini Audit Going Concern. Jurnal IImiah Cendekia Akuntansi Vol. 3 No. 3.

Gavious, I. 2007. Alternative Perspectives Deal With Auditors' Agency Problem, Critical Perspectives On Accounting 18, 451-467

Ghozali, Imam. 2006. Aplikasi Analisis Multivariate dengan Program SPSS. Semarang: Badan Penerbit Universitas Diponegoro.

Gujarati, Damodar. 2003. Ekonometrika Dasar, Erlangga: Jakarta

Healy, P. \& Lys, T. 1986. Auditor Changes Following Big Eight Takeovers of Non Big Eight Firms. Journal of Accounting and Public Policy (Winter), 251-265.

Institut Akuntan Publik Indonesia. 2011. "Standard Profesional Akuntan Publik". Jakarta: Salemba Empat.

Januarti, Indira. 2009. Analisis Pengaruh Faktor Perusahaan, Kualitas Auditor, Kepemilikan Perusahaan terhadap Penerimaan Opini Audit Going concern (Perusahaan Manufaktur yang terdaftar pada Bursa Efek Indonesia. Makalah Disampaikan dalam Simposium Nasional Akuntansi XII. Palembang: 4-6 November.

Jensen MC, dan W.H Meckling. 1976. "Theory of Firm Managerial Behaviour Agency Cost \& Ownership Structure". Journal of Financial Economics Vol. 3 Pg 305306.

Komalasari, Agrianti, 2004. Analisis Pengaruh Kualitas Auditor dan Proxy Going Concern terhadap Opini Auditor. Jurnal Akuntansi dan Keuangan. Vol. 9, No. 2: 1-15.
Mada, B. E., \& Laksito, H. 2013. Pengaruh mekanisme corporate governance, reputasi $K A P$, debt default dan financial distress terhadap penerimaan opini audit going concern (Doctoral dissertation, Fakultas Ekonomika dan Bisnis).

Marisi P. Purba, 2009. Asumsi Going Concern, Suatu Tinjauan terhadap Dampak Krisis Keuangan atau Opini Audit Laporan Keuangan. Graha Ilmu : Yogyakarta.

McKeown, J. Mutchler, J dan Hopwood W. 1991. "Towards an Explanation of Auditor Failure to modify the Audit Opinion of Bankrupt Companies". Auditing: A Journal Practice \& Theory. Supplement. 1-13.

Oktavia, 2010. Going Concern dan Implikasinya terhadap Pelaporan Keuangan dan Auditing, Universitas Kristen Krida Wacana, Fakultas Ekonomi, Jurnal Akuntansi, Volume 10, Nomor 3, September 2010: 305328.

Palmrose, Z. 1984. The Demand for Quality Differentiated Audit Service in an Agency Cost Setting: An Empirical Investigation. $1984 \quad$ Auditing Research. 32, 2, 241-261.

Praptitorini, Mirna Dyah \& Januarti Indira. 2007. Analisis Pengaruh Kualitas Audit, Debt Default dan Opinion Shopping terhadap Penerimaan Opini Going Concern. Jurnal Akuntansi dan Keuangan Indonesia Volume 8 - No. 1, Juni 2011.

Prayitno, Mokhamad Yog. 2011. Analisis Faktor -Faktor yang dapat Mempengaruhi Auditor dalam Pemberian Opini Audit Going Concern (Studi Empiris pada Perusahaan Lq-45 (Blue Chip) yang Terdaftar Di BEI). Skripsi. Universitas Pembangunan Nasional "Veteran" .Yogyakarta.

Rahman, Abdul \& Siregar, Baldric. 2011. Faktor - Faktor yang Mempengaruhi 
Kecenderungan Penerimaan Opini

Audit Going Concern Pada Perusahaan Manufaktur yang Terdaftar di Bursa Efek Indonesia. Jurnal IImiah. Sekolah Tinggi IImu Ekonomi YKPN. Yogyakarta.

Ramadhany, Alexander. 2004. Analisis FaktorFaktor Yang Mempengaruhi Penerimaan Opini Audit Going Concern Pada Perusahaan Manufaktur Yang Mengalami Financial Distress Di Bursa Efek Jakarta. Jurnal Maksi, Vol 4.

Ross, Stephen, R. W. Westerfield, and J. Jaffe. 2002. Corporate Finance. McGrawHill: New York.

Sofyan Syafri Harahap. 2012. Teori Akuntansi. Jakarta: PT Rajagrafindo.
Sugiyono. 2007. Metode Penelitian Bisnis. Cetakan ke-10. Bandung: Alfabeta.

Surbakti, Meliyanti Yosephine. 2010. FaktorFaktor yang Mempengaruhi Penerimaan Opini Audit Going Concern (Studi Empiris Pada Perusahaan Manufaktur Di Bursa Efek Indonesia. Jurnal IImiah.

Wahyu, Lestari Puji. 2009. Pengaruh Financial Distress, Debt Default, Auditor Changes dan Opini Audit Tahun Sebelumnya terhadap Opini Audit Going Concern Pada Perusahaan Property and Real Estate yang Terdaftar di Bursa Efek Indonesia. Universitas Sebelas Maret, Fakultas Ekonomi, Jurnal Akuntansi. Surakarta. 